\title{
O CAFÉ E OS CAFÉS EM PARIS $\left(^{\star}\right)$.
}

\author{
JULES LECLANT \\ - Instituto Francês de Arqueologia Oriental (Cairo).
}

Em meio ao Tableau de la Régence (1), Michelet se interrompe sùbitamente para, de um pequeno fato de costumes, tirar um resumo da história da humanidade. "As três idades do café", escreve, "são as idades do pensamento moderno", e analisa com sutileza o fino aroma do café árabe, depois o sabor mais acre do café indiano, "café de terra vulcânica, que fêz a explosão da Regência e do espírito nôvo", - finalmente o gôsto cheio, encorporado, tão nutritivo quanto excitante do café das Antilhas, que "alimentou a idade adulta do século, a idade forte da Enciclopédia". Pode-se não dar crédito ao "historiador visionário" quando afirma que "os profetas reunidos no antro de Procópio viram no fundo da negra beberagem o futuro raiar de 89"; é preciso reconhecer, entretanto, que o uso do café dá ao século XVIII uma fisionomia bem diferente daquela do século XVII, bebedor de vinho. Saint-Amant freqüentava as tabernas, buscando inspiração

no dôce canto das orgias, no brilho das caras embebedadas.

Molière, La Fontaine, Racine, Chapelle e Boileau iam ao cabaré para beber vinho e conversar; mas os filósofos, - Fontenelle, Diderot, Marmontel, d'Alembert, Beaumarchais, Voltaire, - freqüentam os cafés, estas "fábricas de talento, tanto boas como más" (2), e pedem ao "sóbrio licor possantemente cerebral" um exicitante à sua crítica. Assim, o espírito francês foi se modificando à medida que se difundia o uso da nova bebida e que assinala uma das etapas da

\footnotetext{
$\left.{ }^{*}\right)$. - Trađuçáo, devidamente autorizada, por E. Simōes de Paula, de artigo publicado in Annales (Economies-Sociétés-Civilisations, ano VI, janeiromarço de 1951, no 1, pp. 1-14). (Nota da Redação).

(1). - MICHELET, Histoire de France, t. XVII ("La Régence"), cap. VIII.

(2). - Encyclopédie ou dictionnaire raisonné des sciences, des arts et des métiers, Paris, 1751, t. II, p. 529 (Vo caffés).
} 
conquista da sociedade francesa por influências orientais (3). Tanto para a história das idéias como para a história dos costumes, interessa saber qual foi a posição do "licor de café" e da "casa de café" em Paris, a partir do século XVII.

Os primórdios do café foram muito modestos. E' através de uma longa série de vicissitudes que êle obtém foros de cidadania francesa, conquistando pouco a pouco a preferência popular. Introdução do grão em 1644; sucesso absoluto da beberagem em 1693: foram necessários 50 anos para vencer todos os obstáculos.

Obviamente, foram "viajantes" os introdutores do café na França, então muito usado nos países turcos, do Bósforo ao vale do Nilo. Marselha, "pôrto do Oriente", acolheu-o em 1644. Voltando de Constantinopla, onde acompanhara $M$. de la Haye, o senhor de la Roque (4) trouxe, com o café, os utensílios necessários para prepará-lo e bebê-lo: orgulhava-se particularmente de "xícaras de velha porcelana de grande beleza, e de pequenos guardanapos de musseline bordados a ouro, prata e sêda", objetos mais de colecão do que de uso diário. Seu diminuto gabiente à turca "provocava forte curiosidade" e o público convidado a provar a beberagem compunha-se de viajantes amigos, afeitos, como La Roque, aos costunes orientais. Outros negociantes de Marselha passaram então a fazer certo uso do produto. Mas, durante quinze anos, a bebida não ultrapassou o âmbito de meios muito restritos.

Em 1657, introduzidos por Jean de Thévenot, o café aparece pela primeira vez em Paris. O célebre viajante (5), tendo trazido do Egito uma provisão do precioso grão, presenteou alguns amigos (6), nem todos orientalistas como M. de la Croix, intérprete do Rei em língua turca, que nos conservou a lembrança (7). Algumas pessoas da alta sociedade, em busca de novos prazeres, gabaram-se mesmo de conhecer a fundo os fabricantes italianos de café. Em 1660, um tal senhor More, por intermédio do maître de hotel de Mazarino, veio integrar o grupo de seus cozinheiros, enquanto Andréa Salvator preparava a nova beberagem para o marechal de Gramont, "muito curioso dêsse tipo de coisas". Esses dois hábeis italianos distingüiam-se "em distilar tôda sorte de flôres, frutos, grãos e outras coisas, tanto a

\footnotetext{
(3). - P. MARTINO, L'Orient dans la littérature française aux XVIIe et XVIIIe siècles, Paris, 1906, p. 347.

(4). - Esse fato e relatado por seu filho JEAL DE LA ROQUE, p. 363. Vêr, no fim, a Bibliografia das obras citadas.

(5) . - J.-M. CARRE, Voyageurs et écrivains français en Egypte, Le Caire, 1932, t. I, p. 15 .

(6) - - Jean de THÉVENOT consagrou diversas páginas ao "cahvé" e aos "cahvenes" (cabarés públicos de cahvé") entre os turcos, na narrativa de suas viagens: Voyages de $M$. de Thévenot en Europe, Asie, Afrique (lère éd., 1664) .

(7). - GALLAND, obra citada.
} 
quente como a frio, e em preparar chocolate, chá, café" (8). O grão de café, raro e precioso, era vendido a 80 francos a libra.

Clientela assás restrita ainda. O grande público continuava a ignorar a existência do café. Donde a surpresa dos leitores da Muse de Cour, ao descobrirem, em 1666, um poema de Subligny cantando as virtudes do kavé:

Que cura em menos de uma ave-maria

Quando o resto não pode curar num ano... (9).

Um acontecimento bem "parisiense" estaria presente à origem da preferência que, sùbitamente, "lançou" a negra beberagem.

Ao fim de vários anos. as relacões entre o Sultão e os Cristãos foram rompidas, dado os sucessivos insultos, roubos, aborrecimentos, etc., que atingiam nossos embaixadores e negociantes no país turco. Um destacamento militar comandado pelo duque de Beaufort acabava mesmo de ser enviado em socôrro dos venezianos sitiados em Candia nelo Grão Vizir. De repente, tem-se notícia de aue Mnhammed IV, entregando-se a melhores sentimentos. enviava a Paris um embaixador (10). Este desembarcou em Toulon a 4 de agôsto de 1669, acompanhado de umas vinte pessoas importantes e de criados - e eis que tôdas as atencões se voltam para Soliman Aga. Mutaferraca (11). A sua nassagem. as cidades saudaram-no com salvas de canhão. Em Paris, o nrónrio rei recebeu-o com solenidade desusada (12). Todavia. longe de se enternecer com tamanhos sinais de atenção, o turco, muito ao contrário, queixou-se de que o rei não se levantara a fim de receber sua carta, e retirou-se muito descontente. No plano político. a embaixada viu-se perdida; porém, em se tratando da literatura e dos costumes. verificou-se exatamente o contrário, - pois Mustapha Raca está na origem do Bourgeois Gentilhomme e

(8). - AUDIGER, obra citada.

(9). - 2 de dezembro, 1666, p. 225. O advogado, espirituoso, para que melhor o entendessem, tinba neressidade de explicar a ortgem do produto e de exaltar suas qualidades:

\author{
E um licor árabe. \\ Ou turco se deselais \\ Que no Levante todos tomam... \\ Passou pela Itália \\ Pela Holanda e entre os inglêses \\ Que o consideram muito útil, \\ F armênios que estăo nesta cldade
}

(10). - Cf. na Bibliografia o artigo citado de A. VANDAL

(11). - Título turco que indica determinada funçăo da criadagem do sultão, interpretado como o nome do embalxador que fol chamado em Parls Mouta Faraca ou Mustapha Raca.

(12). - Journal d'Olivier d'Ormesson (ed. Chéruel), t. II, p. 577. - Gazette de France, 7 e 19 de dezembro de 1669 (p. 1165 e 1197) : relaçáo da "audiencia concedida por S. M. ao enviado do Grande Senhor'. 
difundiu o uso do café na França. A dar crédito a uma anedota de la Martinière (13), seria caso de se zombar dos desdens do enviado da Sublime Porta, já que teriam inspirado as "turcadas" burlescas do Bourgeois Gentilhomme: pondo em cena o Oriente travestido, Molière vingava Luís XIV (14) ...

Com efeito, após ter se mostrado tão orgulhoso com Luís XIV, Soliman Muta Faraca, belo homem de uns cinquienta anos, começou a receber, principalmente senhoras. "Belas e jovens escravas, adornadas com ricas vestes turcas, apresentavam às damas pequenos guardanapos de linho adamascado guarnecidos com franjas de ouro e serviam o café em xícaras de porcelana fabricadas no Japão". A gente se comprimia na loja exòticamente decorada, atraída mais pelo encanto de uma conversação picante - o turco era "homem de espírito" (15) - do que pela beberagem de sabor bastante acre. Porém, Mustapha aumentou sua amabilidade até o ponto de oferecer açúcar com o café. E a satisfação foi completa. Quando partiu (16), os que haviam tido o inestimável privilégio de privar de sua hospitalidade, empenharam-se em fazer degustar a seus amigos e convidados a beberagem tão comentada. Também na alta sociedade se difundiu a moda de servir café nas recepções.

Os burgueses outrossim, cêdo quizeram saborear a novidade. A fama do "licor árabe" foi explorada pelos negociantes da capital, sempre prontos a satisfazer a curiosidade pública. Surgiram então em Paris, a partir de 1671, "numerosas lojas onde se vendia pùblicamente o café". E' o que lemos no tratado De l'Usage du Caphé, du Thé et du Chocolate, publicado nesse mesmo ano em Lyon (17), o livro resumia diversas opiniões a respeito do bunchum (o grão) e da bebida obtida. O nôvo produto, vendido em grãos, era utilizado mais como droga do que como bebida agradável; certo prospecto espalhado pelos negociantes de café elogiava justamente suas propriedades terapêuticas (18). Dest'arte, o café teria sido apenas uma prefiguração

(13). - E. DESPOIS e P. MESNARD, Oeuvres de Molière (Col. des Grands Ecrivains), t. VIII, p. 10. Cf. M. PAQUOT, Les étrangers dans les divertissements de la Cour, Bruxelas, 1931, p. 161 e seguintes.

(14) - VANDAL, art. citado. p. 80.

(15). - LEFEVRE d'ORMESSON, obra citada.

(16). - Despediu-se do senhor de Lyon nos fin de maio de 1670 e deixou Toulon em 22 de agôsto (Mémoires de d'Arvieux, t. IV, p. 251).

(17). - Tratado que pode ser atribuido a SPON.

(18). - "O café é um fruto que cresce nos desertos da Arábia, de onde é transportado para todos os domínios do Grande senhor: que, sendo ingerido, seca todos os humores frios e úmidos, expulsa os ventos, fortifica o figado, alivla os hidrópicos em virtude sua qualidade purificadora; soberana contra a galha e a corrupção do sangue; refresca o coraçăo e seu movimento vital, auxilia os que sofrem do estômago e de inapetência; é igualmente aconselhado para as indisposiçōes de cérebros frios, úmidos e pesados.

A fumaça que expele é boa contra os defluxos dos olhos e ruidos nos 
da quina medicinal se não fôsse, ao mesmo tempo, elogiado nas barracas das feiras como a bebida por excelència.

Os armênios que, desde 1666 - como observou Subligny traziam a Paris pacotes de café provenientes do Sul, resolveram entáo tirar partido da acentuada preferência dos parisienses pelo café, abrindo lojas onde se vendia ùnicamente a negra beberagem. E' possível que se tenham inspirado no exemplo de Marselha - proneira no assunto - onde se inaugurou, em 1671, um armazém do "licor do café". Em 1672 (19), surgiu em Paris na Feira Saint-Germain (20), uma "casa de café", mantida por um certo Harouthion ou Pascal, que obteve grande sucesso (21). Fechada a Feira, Pascal mudou-se para o cais da Escola (22), onde, por dois soldos e seis dinheiros, servia uma xicara de café. Mas, aí, o sucesso abandonou-o; os treqüentadores do cais relutavam em freqüentar um estabelecimento cujos únicos fregueses eram orientais e alguns cavaleiros de Malta. Pascal viu-se obrigado a fechar a loja e rumar para Londres. A fim de prosseguir no comércio? Provàvelmente. Na capital inglêsa, as coffee-houses, abertas depois de 1652, tinham conquistado de tal torma o favor do público que, em 1675, temendo sua hostilidade, Carlos II tentou suprimır "êsses antros de gente desclassificada, que discute e difunde opiniões capciosas, maliciosas e escandalosas, com o intuito de difamar o govêrno de Sua Magestade e perturbar a paz e o repouso da nação" (23) .

Em Paris, Pascal tivera um precursor. Atraído pela clientela abundante e fácil que oferecia a Feira Saint-Germain, seu empregado Procópio associou suas magras economias de "garção de café" àquelas de um outro chamado Logerot - e alugou na Feira a loja 121, na esquina da rua Mercière com a Quatrième Traverse. A idéia de "casa de café" instalada em cidade foi retomada por outro armênio, Maliban,

ouvidos; excelente para a respiraçäo fraca, para constipaçóes que atacam - pulmäo, dores do baço, para os vermes, constitut alivio extraordinário após ter bebido ou comido em excesso. Nâo há nada melhor para as passoas que comem muita fruta". (SPON, obra citada, p. 23-25).

(19). - Os historiadores do café (p. ex. FRANKLIN, obra citada, p. 32) indicam que, a partir de 1643, um oriental teria aberto, sem sucesso, um café na galeria coberta sob o Petit-Châtelet, que ligava a rua Saint-Jacques ao Petit-Pont. Ninguém dá referências; não nos fol possível encontrar confirmação do fato.

(20). - Parece ter sido CONSTANT d'ORVILLE o primeiro a apresentar a data de 1672, Melanges tires d'une grande bibliothèque - (citado por JAL, Dictionnaire critique, Paris, 1867, p. 445). Cf. P. FROMAGEST, art. cit.

(21). - F. MACLER, Les Arméniens (art. cit.).

(22). - Atualmente cais do Louvre.

(23). - Encyclopedia Britannica (9e éd.), t. VI, p. 110 (Vo Coffee). 
que se estabeleceu na rua de Bussy, perto do Jeu de Paume de Metz. Após curta passagem pela rua Férou, êle voltou à primeira loja e passou a vender tabaco e cachimbos à moda oriental. Indubitàvelmente fracassou, pois logo partiu para a Holanda. Sucedeu-Ihe um empregado - um tal Grigor ou Grégoire, originário de Ispahan, que, ardilosamente, procurou se estabelecer perto da Comédie Française, que funcionava então à rua Mazarino. Comediantes, literatos e jornalistas adotaram o hábito de se encontrar na loja de Grégoire. O café - lugar onde se conversa -, estava fundado (24).

Para tomar café, já não era preciso entrar nas pequenas barracas dos botequineiros orientais. Mercadores ambulantes percorriam as ruas, vendendo café a domicílio. Dentre êles, celebrizou-se um coxo chamado Candiot, sem dúvida cretense, que gritava pelas ruas: "Café!" Envolto num guardanapo bem limpo, trazia numa das mãos um rescaldo que sustinha uma cafeteira - e na outra uma espécie de reservatório de água; na frente, um cesto de ferro esmaltado de branco com todos os utensílios necessários (25). Por dois soldos, enchia uma xícara, fornecendo também o açúcar.

Candiot tinha concorrentes. Os nomes de Joseph, oriental, e de Etienne de Alepo chegaram até nós (26). Foram orientais os artesãos obscuros da aclimatação do café em Paris. Durante tôda a segunda metade do século XVII, armênio foi sinônimo de mercador de café (27).

Os locais onde se consumia café, entretanto, não passavam de barracas infestadas de tabagismo. Surgiu então à rua Fossés Saint-Germain um estabelecimento de aspecto inteiramente diferente, agradável, limpo, luxuoso mesmo: o primeiro verdadeiro café, fundado por Francesco Procópio Coltelli .

Discutiu-se muito, discute-se ainda sôbre as origens do personagem. Teria nascido em Palermo, na Sicília, em Florença como pre-

(24). - Quanto aos fundos da rua de Bussy, Gregório cedeu-os a um persa' chamado Makara que os vendeu, por sua vez, a um flamengo apelidado Le Gantois.

(25). - JEAN DE LA ROQUE, obra cit., p. 337.

(26). - Acumularam suficiente dinheiro para se estabelecer, o primeiro na ponte Nôtre-Dame, o segundo na rua Saint-André-des-Arts, quase em frente à Ponte Saint-Michel.

(27). - A. FRANKLIN, Dictionnaire historique des arts, métiers et professions exercées dans Paris depuis le XIIle siècle, Paris-Leipzig, 1906, Vo Arméniens. - Em La Foire Saint-Germain, comédia de Dancourt (1696), um dos personagens, Loranse, "negociante de café, caracterizado de armênio", confessa "ser armênio naturalizado há três semananas". 
tende seu sucessor Dubuisson (28), ou ainda em Paris, onde um certo Procópio Coltelli se estabeleceu na época de Catarina de Médicis? A questão é resolvida por um "Extrato da Minuta do Tribunal de Contas de Paris, ano 1684, p. 13" (29), atestando que Francesco Procópio Coltelli era siciliano. Seu registro de casamento (30) permite acrescentar: nascido em 1650, filho de Onófrio Coltelli e de Domênica Semarqua. Após que atribulações o siciliano [em quem se deve deixar de ver um gentilhomem arruinado (31) ] - surge na Feira, onde se emprega no negócio de Pascal? Ignora-se. Seguiu o patrão ao cais da Escola; fechado o estabelecimento, voltou, como vimos, à Feira Saint-Germain, associou-se a um certo Logerot a fim de alugar uma loja, e ganhou em pouco tempo dinheiro suficiente para poder, em 1675, casar-se com Marguerite Crouin: de 1676 a 1688, teve oito filhos. Suas relações parecem localizar-se nos meios italianos (32). Mas em 1684 o siciliano, à frente de um próspero negócio, naturalizou-se. A partir dêsse momento, Procópio Couteau pertence, se não à história da França, p̉elo menos à história dos costumes franceses.

Antes de se naturalizar, Procópio fazia parte, desde 1676, da comunidade dos "distiladores-botequineiros". Enquanto seu registro de casamento o designa (em 1675) como "mercador", é chamado "distilador" em 1677 e "mestre-distilador" em 1677 e 1678 nos registros de batismo dos filhos. Em 1676, com efeito, os "mestres-botequineiros, mercadores de aguardente", haviam sido contemplados com nôvo estatuto; o artigo III dava-lhes a "faculdade de compor e vender... café em grão, em pó e sob forma líquida" (33). "Distilador-

(29). - ARQUIVo NACIONAL, p. 2695, publicado por A. BRUel, Butl. Soc. Hist. du VI Arrond. de Paris, 1898, p. 155. O incêndio do Tribunal de Contas em 1737 privou-nos exatamente dos documentos de naturalização que, sem dúvida, teriam fornecido indicaçóes mais completas sôbre a origem de Procóplo.

(30) . - Celebrado na igreja Saint-Sulpice em 26 de fevereiro de 1675. "Casamento de Procópio Couteau, mercador de vinte e cinco anos de idade, fillho do falecido Onofre Couteau e de Dominique Somarque, morador à rua de Tournon". Couteau (faca) - e não Couteaux (facas) - que serja a tradução exata de Coltelli.

(31). - MOURA e LOUVET, obra cit. (p. 22) são de opinião que Procópio seria gentilhomem ("Procopio dei Coltelli"). Baseam-se na existência de uma familla parlamentar de Cousteau. Na verdade, apenas os descendentes do botequineiro enriquecidos e estimados é que foram agraciados com titulos de nobreza. (A. BRUEL, obra citada, p. 156-158).

(32). - Sua primeira filha é batizada por um "gentilhomem italiano", e a terceira por um "gentilhomem de Messina"; em 1688, Marie-Anne é apadrinhada na pia batismal por Don Cristofolo Papi Duca di Pratoamene. Seriam todos compatriotas os mais fiéis clientes de Procópio Coltelli, contentes de se reencontrarem em Paris num dêsses cafés que a Itália já conhecia? Registros de batismo em A. JAL, Dictionnaire critique de biographie et d'histoire, 1867, p. 426. ("Dicionário crítico de blografia e de história).

(33). - R. de LESPINASSE, Histoire Général de Paris. Les métiers et corporations de la ville de Paris. Oräonnances généralees. Métiers de l'Alimentation, Paris, 1886. 
-botequineiro", Procópio abandonou a Feira Saint-Germain, escolhendo a rua de Tournon (34). Em 1686 (35), transportou-se à rua Fossés Saint-Germain, onde fundou o estabelecimento que, no curso dos séculos, deveria conhecer a celebridade sob o nome de "Café Procópio" (36). Procópio alugou as duas casas vizinhas, o que the proporcionou grande espaço para trabalhar: "O terreno extendia-se ao longo dos fossos da cidade, entre as portas de Saint-Germain e Bussy, sendo a contra-escarpa" (37) . O ousado siciliano, derrubando as divisões, dedicou o rés-de-chão dos dois imóveis ao café, e aí colocou mesinhas de mármore, cômodas e graciosas, pendurou no teto lustres de cristal, ornamentou enfim as paredes com elegante tapeçaria e - supremo refinamento - com vidros e espelhos. O café tornava-se digno de se constituir em local de encôntro de pessoas honestas... e de apreciadores de vinhos

Aos talentos de preparador de café, o "mestre-distilador" acresen tava os de manipulador de licores e drogas múltiplas. Possuia também estoque variado de vinhos capitosos: vinho moscatel, vinhos de Espanha, de Saint-Laurent e de Ciotat, e tôda uma palheta de sábias misturas: rosólio, "orvalho do sol", que permitia ao degustador saborear a harmonia do funcho, do anís, do coentro, do endro e da alcaravia esmagados e macerados ao sol na aguardente; "populo", onde se fundiam os perfumes do cravo da India, do almiscar, do âmbar, do pimentão, do açúcar, do anís, do coentro e do alcool; água de cidra e "licor do perfeito amor"; sorbec, composto de limão, almiscar, âmbar e açúcar; frutas confeitadas, cerejas, framboesas ou nozes; caldos de geléias e finalmente glacés de frutas e flôres de múltiplos perfumes, pois o "artista" (38) siciliano lançou, desde o fim do século XVII a fórmula do "café gelado": feito para reanimar e para refrescar.

E' então que, por feliz concidência, vasta clientela vem se oferecer a Procópio. Expulsos em 1687 da rua Mazarino pela hostilidade dos jansenistas, seus vizinhos, os Comediantes do Rei, instalaram-se

(34) . - Guide du Vieux Paris, por de ROCHEGUIDE e DUMOULIN.

(35). - G. de WISSANT, obra cit., p. 65, dá sem referência a data de 1684. Não menciona a etapa intermedfária da rua de Tournon.

(36). - Eossivel que tenha sido denominado por um de seus parentes distantes: o local onde se instala - um estabelecimento de banhos com a insignia do "Santo Sudário de Turim - fôra mantido pelos descendentes do Procópio Coltelli vindo a Paris depois de Catarina de Médicis.

(37) . - Memórias por A. COUTEAU, negociante merceeiro-botequineiro em Paris, intimado, contra Jean Maurice Durand de Chastas, secretário do Rei, coletor geral das finanças de Champagne, apelante (G. de WISSANT, obra cit., p. 66-67).

(38). - O têrmo é de seu sucessor DUBUISSON, Art du distillateur (1779). 
na sala do Jeu de Paume do senhor de l'Étoile, rua Fossés Saint-Germain, bem em frente ao Café Procópio, e construiram teatro nôvo; em 18 de abril de 1689, a Comédie Française com sensacional representação de Phêdre e Médecin malgré lui sua nova casa de espetáculos (39) . No próprio recinto do teatro vamos encontrar Procópio, pois alugara aí o "camarote da limonada", instalando uma "distribuidora de licores doces". Fato capital: o Café Procópio tornou-se verdadeiramente o quartel-general de todos que mantinham relações com a Comédie .

Até essa época, Procópio recebia principalmente a visita dos jogadores de bola do Jeu de Malus (situado atrás do café), dos jogadores de pela do senhor de l'Étoile e de alguns espadachins da vizinhança. Encontrara também boa clientela entre os numerosos transeuntes que percorriam a encruzilhada de Bussy, então o verdadeiro centro de Paris sôbre a margem esquerda. Das ruas Dauphine, Mazarine, Saint-André-des-Arts, des Boucheries, de Condé, ia-se prazeirosamente até a rua dos Fossés Saint-Germain, para aí tomar um refrigerante e saborear uma xícara de café. Mas, uma vez construida a Comédie, afluiu a clientela dos autores, comediantes, novelistas, gente de letras, elegantes senhores ou fiscais atraidos a essas paragens pelos encantos dos comediantes. Os criados, então, em costumes orientais, envoltos em amplas vestimentas e trazendo à cabeça bonés de pele, apresentavam pequenas xícaras de bebida fumegante a uma clientela deveras heterogênea (40): jovens cavalheiros, belos e elegantes, abades galantes deliciando-se com doces e confeitos; casais discretos refugiados no meio da multidão e do ruído; sábios e letrados que "conferenciavam sôbre matérias de erudição, sem violências e sem cerimônia, por assim dizer, divertindo-se" (41). Diante da xícara de café, tagarela-se; "a conversação acompanha obrigatòriamente o café ou o chá, ela é quase sua verdadeira razão de ser". O café, mal acabara de nascer, já era um café literário.

Outrossim, desde o comêço, é um café político. Aí se discutem negócios - os mais graves - do govêrno. E o poder se interessa imediatamente por êsses possíveis centros de oposição. Em 27 de

\footnotetext{
(39). - Cf. JOANNIDÈs, La Comédie Française de 1680 a 1920, etc. (Vêr a Bibliografia).

(40). - O café se oferece como uma mina inexgotável de "retratos" e de "caracteres". A diversidade de tipos de clientes fornece em 1694 o assunto para uma comédia que não teve sucesso, pois foi representada apenas uma vez. Impressa com o título de Le Café, comédie, chez P. Aubouin en l'année de 1694. Todos êsses caracteres são também descritos pelo cavaleiro de Mally em seu Entretiens aes cafés de Paris et les différends qui $y$ surviennent (1762).

(41) - Jean de La ROQUE, (obra cit. 380).
} 
dezembro de 1685, Seignelay escreve a La Reynie (42): "O Rei foi informado de que, em diversos locais de Paris onde se bebe café, fazem-se assembléias de tôda casta de gente e particularmente de estrangeiros. Sôbre o assunto Sua Magestade ordena-me de vos perguntar se não julgais conveniente impedir seu funcionamento para o futuro".

Mas o sucesso dos novos estabelecimentos foi tão retumbante que o Lugar-Tenente de Polícia resolve não acatar a recomendação do Secretário de Estado. Ao lado do Café Procópio, desenvolveram-se muitos outros: na Foire Saint-Germain as modestas barracas transformaram-se em salas elegantes, onde os garçons "armênios" serviam o café em cafeteiras de prata; na esquina das ruas Dauphine e Christine, Laurent (43) fundou um café que se tornou ràpidamente famoso; na rua Saint-André-des-Arts, Estêvão de Alepo fixou-se após ter, durante anos, percorrido as ruas a gritar: "Café!" Em breve, todo o centro elegante da vida parisiense localizado na encruzilhada de Bussy, Foire Saint-Germain e a Seine, rendera-se à nova fórmula: era de bom tom encontrar-se no càfé.

Simultâneamente o café ganhara a preferência dos particulares, não sem dificuldades porém.

Depois do grande movimento favorável de 1670 , manifestou-se séria reação liderada pela Faculdade de Medicina: receosos das propriedades excitantes do café, numerosos médicos haviam-no condenado. A correspondência de Mme de Sévigné testemunha a oposição da classe médica à nova bebida, e us atitudes vacilantes da Côrte e das pessoas de sociedade com relação ao nôvo produto. Em 10 de maio de 1676 (44), ela informa à filha que o café acaba de ser "vergonhosamente expulso" da casa de Mlle de Méri. "Após tais desgraças, pode-se contar com a fortuna?" (45) Em 1679, novamente, informa Mme de Grignan sôbre as prevenções de Du Chesne, médico de seus amigos: "A fôrça que julgais advir do café não passa de um falso bem" (46). No mesmo ano, o senhor Colomb, na condição de agre-

(42). - ARQUUVO NACIONAL, Registros do Secretário de Estado da Casa daRef, 0i29, fol. 568. Assinalado por E. LELONG, art. cit, pág. 79, mas já publicado anteriormente, em 1850 , por DEPPING, Correspondance administrative sous le règne de Louis XIV, t. II, p. 575.

(43). - Sôbre o Café Laurent, A. FRANKLIN, obra cit. pp. 64 e 279.

(44). - Carta de 10 de maio de 1676 (ed. Monmerqué, t. IV p. 443) .

(45) . - Em 16 de março de 1672, a marquesa escreveu à filha: "Racine fêz comédias para a Champmeslé; não é para os séculos vindouros...". Voltaire sem dúvida confundiu, por descuido, as duas cartas de 16 de março de 1672 e a de 10 de maio de 1676 quando, no prefácio de Irène (1776), atribui a Mme. de Sévigné a frase célebre: "A moda de gostar de Racine passará como a moda do café".

(46). - Carta de: novembro de 1679 (ed. Monmerqué, t. IV p. 78). 
gado ao colégio de médicos de Marselha, demonstrou por sua vez que o uso do café era nocivo aos habitantes dessa cidade (47).

Todavia, um forte partido permanecia apegado ao café. Donde as perplexidades da marquesa: "Du Chesne continua a detestar o café: o frei (Ange) nada diz de mal, escreve à filha em $1680 \ldots$ Será preciso ter a intenção de tomá-lo como remédio? Calderousse está sempre a louvá-lo; o café engorda uns e emagrece outros: eis tôda a extravagância do mundo. Não creio que se possa falar' mais positivamente de uma coisa que oferece tantas experiências contrárias". (16 de fevereiro de 1680).

A facção do café pouco a pouco prevalecia; cêdo iria poder, por sua vez, reclamar sábios tratados, mostrando o bom uso que dêle se podia fazer para a "preservação e cura das doenças" (48). Mas. nôvo revés de fortuna advém: "O café está completamente desgrado, escreve Mme de Sévigné à filha em 10 de novembro de 1688; o Cavalheiro crê que êle esquenta e põe seu sangue em movimento; e eu também, Maria vai com as outras como me conheceis, não o tomo mais". Uma semana depois, é verdade, a marquesa julga que o café poderia "ganhar novamente as boas graças" mas a Côrte parece condená-lo definitivamente: "O café caiu em desgraça e por conseguinte não o tomo mais; não obstante, tinha a impressão que me fazia um certo bem; mas já não sonho mais" (49). E' então que um médico de Grenoble. Monin (50), teve a idéia de adicionar leite e açúcar ao café. A preparação recebeu a aprovação dos derradeiros oposicionistas e a marquesa, seguindo os conselhos de Aliot, médico oficial do Rei. exaltou

(47). - “... Ás partes requeimadas nele abundantes são, com efeito, tăo sutis e dotados de um movimento tão grande que, misturadas à massa do sangue arrastam consigo a princípio tôda a serosidade dos reservatórios da urina e das outras partes do corpo. De lá, atacando o cérebro após ter dissolvido a umidade e os corpúsculos grosseiros, deixam os poros todos abertos, e impedem que os espiritos animais que provocam o sono sejam levados ao meio do cérebro quando êsses poros se fecham. Donde se conclui que essas partes adustas, em virtude de suas qualidades, determinam vigilias muitas vêzes tão obstinadas que o suco nervoso, cuja fôrça é tão necessária à reparação dos espíritos, vindo a faltar completamente, faz com que os nervos se relaxem, trazendo a paralisia e a fraqueza total. E devido à acidês e à secura dêsse sangue já inteiramente abrazado, tôdas as partes ficam tăo desprovidas de suco que o corpo inteiro enfim se reduz a uma horrível magreza".

(48). - "Cheio de enxofre e de sal volátil", êle era - segundo o droguista lionês Philippe Sylvestre Dufour - a verdadeira panacéia. E Nicolas de Blégny "conselheiro médico-artista oficial do Rei de Monsilur, e encarregado por ordem de $\mathbf{S}$. M. da pesquisa e verificação das novas descobertas médicas", dera a palavra final em 1687.

(49). - Cartas de 1, 8 e 23 e novembro de 1688. Ed. Monmerqué, t. VIII, pp. $234,252,281$.

(50). - A. FRANKLIN, p. 59. O café com leite foi a princípio empregado como medicamento contra a tosse e para engordar o doente. 
daí por diante o café com leite ou leite com café, "a coisa mais deliciosa do mundo" (51).

Enquanto sua posição se manteve modesta, o govêrno não pensou siquer um instante em ver no café uma possível fonte de rendas. No dia em que figurou de forma regular nos livros-razão, o govêrno pensou em tirar proveitos substanciais. Com efeito, um edital de janelro de 1692 monopolizou a venda do café em proveito do Tesouro (52). $\mathrm{O}$ arrendatário tinha sòmente o direito de importar e vender o café. o chá, o chocolate, o cacau e a baunilha; para vendê-los a varejo, era necessária uma autorização por escrito, a ser renovada anualmente mediante trinta libras. O preço do café em grão era fixado a quatro francos a libra; o "cafèzinho" a três soldos e seis dinheiros. E mestre François Damame, burguês de Paris, recebia por "seis anos próximos e consecutivos", a contar de $1^{\circ}$ de janeiro de 1692, o privilégio "de vender, fazer vender e debitar sòzinho, com exclusão de todos os outros, todos os cafés, tanto em grão como em pó, o chá, os "sorbecs" e os chocolates" (53).

O café tinha doravante uma existência oficial no Estado (54). Mas iria poder resistir ao enorme aumento de preço que acarretava o nôvo sistema? Em 1690 o café valia de 27 a 28 soldos a libra (55); fôra levado bruscamente a quatro francos a libra. A queda de consumo foi brutal, - do consumo oficial pelo menos, pois a fraude tomou grandes proporções. - Um carta de M. de Berulle, inten-

(51). - Cartas de 29 de janeiro e 19 de fevereiro de 1690. Ed. Monmerqué, t. IX p. 435 e 461 .

(52). - Edito do Rei, baixando regulamento sôbre a venda e a distribuição do café, chá, chocolate, cacau e baunilha, em janeiro de 1692 . - A crer-se no preâmbulo, em breve não se consumiria mais vinho na França: "As bebidas do café, chá, chocolate e sorbec tornaram-se tão comuns que os direitos de Aydes se ressentem de uma diminuição considerável. "Não querendo privar seus súditos do uso dessas bebidas que a maioria julga úteis à saúde", o Rei as arrendava, "propondo-se não tirar qualquer lucro na ocorrência da atual guerra".

(53) . - Decreto do Conselho de Estaco do Rei concernente à venda do café, do chá, do sorbec e do chocolatee, 22 de janeiro de 1692 .

(54) . - Tomaram-se garantias a fim de manter a eficácia do monopólio. Concedeu-se apenas um/dia aos possuidores de estoques para fazer suas declaraçóes; "os empregados e encarregados do chamado Damane" recebiam poderes muito amplos de investigação e contrôle; lutava-se para introduzir o café "por portas outras que nêo Marselha e Ruão... com exceção, todavia, dos cafés que poderăo ser apanhados em alto mar e daqueles que virăo das ilhas francesas". Contra a fraude, resolveu-se que os cafés não poderiam "misturar nem manipular grãos, resinas, favas, nem outras coisas dessa espécie ... sob pena de punição corporal e de quinze libras de multa".

(55) . - Decreto do Conselho de Estado do Rei, de 19 de agôsto de 1692. 
dente de Lyon, inspetor geral (10 de março de 1692) (56) nos informa que "os empregados de Damame (sic) apanharam na alfândega e levaram para sua loja um fardo de 7 a 8 quintais que Mme a Princesa de Wirtemberg, que está num convento do lugar, pede e reclama como sua propriedade e que pretende receber para sua provisão". O intendente complacentemente invoca que "essa princesa consome grande quantidade, já que não tem outros prazeres além de tomar café", mas trata-se òbviamente de um vulgar assunto de fraude.

Todavia, o consumo global tinha realmente que diminuir. "A maior parte dos que o tomavam, hoje se abstem", lemos nas considerações do decreto do Conselho de Estado de 19 de agôsto de 1692 "que reduz e modera o preço do café para 50 soldos a libra, compreendidos o preço do negociante e outros direitos" (57). Esta atenuação não restituiu o vigor a um sistema que amortecia o consumo e encorajava a fraude. Um decreto do Conselho do Rei (58) revogou (59) o privilégio de Damame em maio de 1693. O comércio do café voltava a ser livre; contudo, o café não podia "entrar no reino a não ser pela cidade de Marselha, pagando na entrada do pôrto uma soma de dez soldos por cada libra, pesos de marco. anulados e ultrapassados todos os direitos antigos".

Daí por diante, "licor de café" e "casas de café" podiam sem constrangimento corresponder à preferência sempre crescente do pûblico. O café (60), que surgira modestamente em Marselha, meio século atrás graças a intermediários exóticos - viajantes, italianos, turcos, armênios, sicilianos - e através de contingências variadas e numerosas, tinha conquistado definitivamente o direito de cidadania parisiense. E até nossos dias, "cafés, só em Paris".

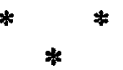

(56). - A. M. de BOISLISLE, Correspondance des Contróleurs généraux des Finances avec les Intendents des Provinces, t. I (Paris, 1874), p. 280, n? 1057.

(57). - "Decreto do Conselho de Estado do Rel que reduz e modera o preço do café para 50 soldos a libra, compreendidos o preço do negociante e outros direitos, de 19 de agôsto đe 1692".

(58). - "Decreto do Conselho de Estado do Rei que revoga o privilégio de venda do café, chá, sorbec, chocolate, cacau e baunilha, estabelecido por edita do mês de janeiro de 1692, em 12 de maio de 1693"'.

(59). - Parece que a organizaçáo foi suprimida devido ao mau funcionamento do sistema. As consideraçöes do decreto revelam ter sido o próprio Damame quem solicitou a revogação. Caberia perguntar, contudo, se năo houve influência de outros fatôres, por exemplo, os importadores marselheses interessados numa maior divulgação do produto. Seria necessário um exame das fontes marselhesas.

(60) . - Em 1694, a Academia escreveu "café" em seu Dicionário. Todavia, encontramos a forma caffé até a Revoluçáo. 


\section{BIBLIOGRAFIA .}

I. - FONTES. - Pertencem a três categorias: tratados sôbre as propriedades do nôvo produto, testemunhando sua preferência junto ao público; - alusões "ao licor de café", e à "casa de café" pelos escritôres e jornais da época; fragmentos de arquivos. Os documentos proveniente dessas duas últimas categorias são indicados em notas. - Damos aquí o catálogo dos tratados:

De l'usage du caphé, du thé et du chocolate (Lyon, 1671), Arsenal, $8^{\circ} \mathrm{S} 1887$ publicado sem nome de autor. Os historiadores do café citam-no sob o nome de Girin, o editor. Em 1716, Jean de la ROQUE o designa como "a tradução francesa por P. S. DUFOUR de um manuscrito latino que lhe caiu nas mãos" (obra citada, p. 306). Segundo BAYLE (Nouvelles de la République des Lettres), o autor seria SPON. Nós pendemos, como o bibliófilo JACOB, para esta segunda hipótese, que atribui ao erudito lionês o primeiro tratado em francês sôbre o café. A obra compreende um resumo dos trabalhos anteriores (Prosper Alpini, etc.), um estudo sôbre o bunchum ou bon (o grão do café) e sôbre a beberagem dêle obtida: "o café".

$\mathrm{Ph}$. -Silvestre DUFOUR, Traités nouveaux et curieux $d u$ café, $d u$ thé et $d u$ chocolate (Lyon, $16^{\circ} 85$ ). Arsenal, $8^{\circ} \mathrm{S} 8117$. O autor, droguista de Lyon, faz um estudo "químico sôbre o café". e estuda suas aplicações terapêuticas. $\mathrm{Em}$ apêndice (p. 207-216), uma Lettre de $M$. Bernier sur le café, onde o célebre viajante estuda os países de origem do grão de café.

Muito próximo, a obra de M. de BLEGNY, conselheiro, médico, artista oficial do Rei e de Monsieur e encarregado por Sua Magestade de pesquisar e verificar as novas descobertas da Medicina, Le bon usage du thé, du café et du chocolat pour la préservation et pour la guérison des maladies (Lyon, 1687). Arsenal, $8^{\circ} \mathrm{S}$ 9777. - AUDIGER, La maison réglée... avec la véritable méthode de fairé toutes sortes d'essences, d'eaux et de liqueurs (Paris, 1692), dá as indicações sôbre os primeiros "botequineiros particulares" e a maneira de preparar o café (B.N., V 31 048).

O mais interessante para nossa pesquisa é GALLAND, o tradutor das "Mil e uma noites": a propósito de um manuscrito árabe da Biblioteca do Rei concernente ao cahvé, escreveu - um opúșculo de 76 páginas - De l'origine et des progrés du café (Caen, - Paris, 1699). Arsenal, $8^{\circ} \mathrm{S} 8115$.

Les Entretiens des Cafés de Paris et les Différends qui y surviennent par $M$. le C. de M.xx (Trévoux, 1702), parece constituir o primeiro testemunho sôbre as "casas de café". O autor, o cavalheiro de Mailly, esboça uma série de "retratos", analisa com certa sutileza certos "caracteres". Além disso, as vinhetas, preciosas, oferecem nessa época uma das primeiras "vistas de cafés": o Museu Carnavalet não possui nenhum outro documento relativo a data tão antiga (Bibl. Hist. Ville de Paris, 921 425).

Em 1718, o marselhês Jean de la ROQUE, após seu livro Voyage dans l'Arabie Heureuse, publicou um Traité historique de l'origine et du progrès $d u$ café... de son introduction en France et de l'établissement de son usage à Paris. $E^{\prime}$ a fonte à qual recorrem, geralmente sem nenhum senso crítico, os historiadores do café. Arsenal, $8^{\circ}$ H 1 230).

Contràriamente ao que se poderia esperar, não há quase nada aproveitável em Jacques SAVARY DES BRUSLONS, Dictionnaire universel de commerce, d'histoire naturelle et des arts et métiers (ed. de 1719, 1721, etc.), nem em Nicolas 
Delamare, Traité de la Police (Paris, 1722 e 1738). Liv. V, Tit. XlVII, Des liqueurs, (T. II, p. 797 e seguintes).

II. - ESTUDOS. - Estamos longe de dispor, para o estudo do café, de um instrumento de trabalho comparável àquele de A. BOURGAUX para o chocolate: Quatre siècles d'histoire du cacao et du chocolat (Bruxelas, s.d. [1938]). Todavia, fundamental é a obra de Alfred FRANKLIN, na série La Vie Privée d'autrefois, intitulada Le café, le thé et le chocolat, Paris, 1893. - Graves defeitos: fontes raramente indicadas, numerosas asserções desacompanhadas de provas; no tocante a certos pontos, soluções hoje inadmissíveis (o café Procópio só aparece em 1702, etc.). Não obstante, êsse livro dispensa consultas aos estudos anteriores, péssimas compilações ou coleções de anedotas insípidas dizendo respeito quase exclusivamente aos cafés do século XVIII.

Ao escrever An historical account of coffee em 1774, Londres, John ELLIS se propunha sobretudo recordar a carreira gloriosa de um produto que fazia a riqueza de São Domingos de quem era "agente". - Em Dissertation sur le café (Paris, 1787), GENTIL se coloca num ponto de vista essencialmente médico.

Os livros de E. F. BAZOT (autor presumido), Les cafés de Paris par un flâneur patenté (Paris, 1819); - A. CONSTANTIN, Histoire des cafés de Paris extraite des Mémoires d'un viveur, (Paris, 1857); - A. DELVAU, Histoire anecdotique des cafés et cabarets de Paris, (Paris, 1862); - A. LEPAGE, Les cafés artistiques et littéraires de Paris (Paris, 1862); se propõem conduzir os leitores através dos cafés dos séculos XVIII e XIX, sem dar quase atenção aos estabelecimentos mais antigos.

Àquêle livro de FRANKLIN, devemos acrescentar alguns estudos mais recentes que o utilizam freqüentemente, completando-o e corrigindo-o às vézes.

Marius ROUSTAN, Essai sur les cafés littéraires, in "Revue de Lyon et du Sud-Est., $1^{9}$ ano, 1906, p. 24-49), elegante e preciso a um só tempo; - G. de WISSANT, Le Paris d'autrefois, cafés et cabarets (p. 65-70, sôbre os começos de Procópio); - J. MOURA e P. LOUVET, Le Café Procope (1829), muito superficial e repleto de erros: ignora o título de naturalização de Procópio, apresenta o tratado de P. S. Dufour como o primeiro livro sôbre o café, etc.; F. FOSCA, Histoire des cafés de Paris, (1934), sintese inteligente, mas muito breve, dos trabalhos anteriores.

Foram estudados com mais particularidade certos meios que influiram sobremaneira na propagação do café. A. VANDAL, L'ambassade de Soliman Aga Mutaferraca; - Revue d'Art Dramatique, t. XI (1883), p. 65-80, estuda as negociações diplomáticas e suas repercussões literárias sem colocar a questão do café; parece ter utilizado apenas uma parte dos documentos, e num sentido parcial; F. MACLER, Les Arméniens. Leçon d'ouverture du cours d̀ l'École des Languest Orzentales vivantes, in "Revue internationale de l'enseignement", 1912, p. 28, et La France et l'Arménie d travers l'histoire (Paris, 1917), p. 18-19; as obras de P. ALIGHAN, Sisakan (Veneza, 1893), p. 456-457 e Honchik hayreneats Hayots (ibid., 1869), t. I, p. 73; - P. FROMAGEOT, La Foire Saint-Germain-des-Prés, in "Bull. Hist. VIe arr.", t. IV, 1901, p. 185-248 e t. V, 1902, p. 46-140; - JOANNIDES, La Comédie Française de 1680 a 1920 (1921); - Mme DUSSANE, La Comédie Française (1921); - E. GENEST e E. DUBERRY, La maison de Molière connue et inconnue (1922). 